\title{
Designing Model for Truck Assignment Problem in Beef Delivery Using DBSCAN Algorithm
}

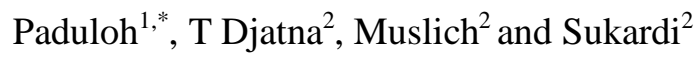 \\ ${ }^{1}$ Department of Industrial Engineering, Bhayangkara Jakarta Raya University, Bekasi, Indonesia \\ ${ }^{2}$ Department of Agro-Industrial Engineering, IPB University, Bogor, Indonesia \\ *Email: paduloh@dsn.ubharajaya.ac.id
}

Article Information
Received:
16 September 2019
Received in revised form:
18 November 2019
Accepted:
03 December 2019
Volume 1, Issue 2 , December 2019
pp. 64 - 67
CUniversitas Lampung
http: //dx.doi.org/10.23960/jesr.v1i2.26

\begin{abstract}
In beef route delivery, many logistics companies have problems in making delivery plans correctly. Most logistics companies have a limited number of trucks, but there are shipping schedules, locations and volumes of demand is not fixed, in addition to returning products with various reasons that must be collected. Therefore the purpose of this study is to assign trucks to fulfill all beef delivery activities at a minimum cost. One reason for research on truck assignments in beef delivery is the high cost of shipping because it uses cold chains. This study uses the DBSCAN method to obtain density values based on customer distance to the central warehouse and the number of delivery requests, the data used in this study is the data of product delivery to customers for 6 months. Clustering research results using DBSCAN show the maximum values for epsilon 0.7 and Minpoints 2 are 3 clusters with 6 noises. with these results divided of trucks based on clusters is 2 trucks for the area of Banten, 7 trucks for the area of Jakarta, Bogor, and Bekasi, 2 trucks for Malang, and Surabaya, and 1 truck for the Bali area and noise or non-permanent delivery.
\end{abstract}

Keywords: Truck assignment, DBSCAN, algorithm, beef delivery.

\section{INTRODUCTION}

A ssignment Truck transportation for the logistic industry is a difficult activity, to balance between customer order, truck capacity and customer location. Routing Delivery logistics are activities delivery to customers based on the customer's location, the number of orders and a predetermined time [1,2]. Routing delivery in the implementation has a very big challenge. Customer location, number of requests and time the customer is not always fixed every day so that the necessary arrangements effective method to obtain the most effective grouping with the cheapest cost.

Beef according to its perishable nature, requires strict handling in handling logistics. meat shipments must use refrigerated trucks, which are then referred to as cold chains $[3,4]$.

Reverse logistics is a supply chain activity that manages the return of products from customers for any reason. This return activity occurs to prevent wasted raw materials or products that cannot be sold or cannot be used by the customer.

Using the reverse logistics system, the product is expected to be able to be reprocessed to restore the minimum data, where objects outside the cluster are considered as noise [5,6].

This study aims to use the DBSCAN method for obtaining the density values based on customer distance to the central warehouse and the number of delivery requests, the data used in this study is the data of product delivery to customers for 6 months.

\section{RESEARCH METHODS}

DBSAN Algorithm can be done by following these steps, Determine the parameters of midpoints, epsilon. Make a starting point or do it use a random method. In accordance with steps 3 - 5 repeat for all points. Calculate epsilon in range density reachable top. The epsilon point formed is more than min points so the point $p$ is the core point and cluster formed. The $p$ can be a border point if there is no point with density reachable to $\mathrm{p}$, continue the clustering process.

In this study, the consideration on using DBSCAN methods and parameter is based on other previous studies, as presented on Table 1 . 
Table 1. Research and Development of DBSCAN Method

\begin{tabular}{|l|l|}
\hline Ref. & \multicolumn{1}{|c|}{ Research Area } \\
\hline$[7]$ & Reason for used DBSCAN \\
\hline$[8]$ & Stock Market Prediction \\
\hline$[9]$ & Mis claim, unfixed and Approximation \\
\hline$[10]$ & heavily skewed data \\
\hline$[11]$ & Exploration and analysis areas using \\
\hline
\end{tabular}

This uses 6-month of delivery history for distribution process and reverse activity in one sample company in West Java, Indonesia called PT. Cianjur Artha Makmur. Data Delivery collected from historical database in the company. From the raw data, the analysis is as the following framework of study as presented in Fig 2.

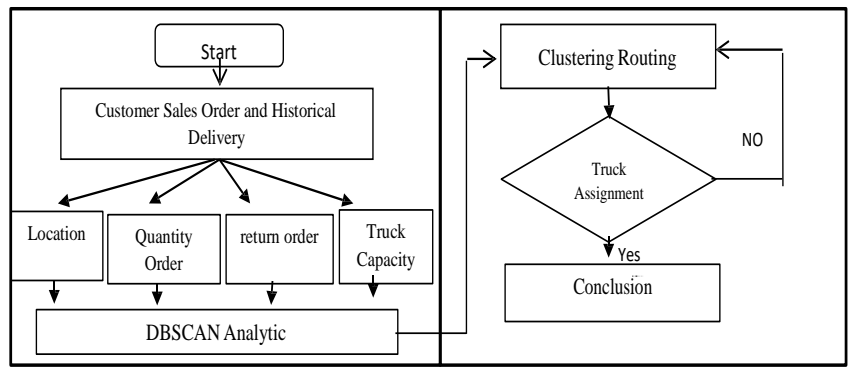

Fig. 2. Research Flow Chart

\section{RESULTS AND DISCUSSIONS}

\section{A. DBSCAN Analysis}

Data clustering management with DBSCAN, according to Figure 3 the process begins with data collection and selection. The data used is data on the delivery of beef products to customers within 6 months. After complete data, data transformation is done to convert raw data into desired data fields in the clustering process based on the DBSCAN Algorithm. The clustering process will produce several clusters. The average value of each cluster is the basis for route delivery distribution based on 12 vehicle fleets owned by the company. The cluster formed is tested for its validity level to get the best number of clusters.

The final stage is the determination of the type of fleet used and the amount based on the number of customers, the number of orders and the location of the customer. In actual condition company has 12 trucks for distribution and handling the customer request, some of the truck has a different volume.

Company has 250 active customers with a different type of order, some of the customers are a customer with routine order with any qty order, others customer are not routine order and the last order with the incidental request. Location of the customer is in the Jakarta area, West Java, East Java, and Bali.
The fields used in the clustering process are arranged in one table so that the data can represent the values in the data transformation process in accordance with existing conditions. The first step in analyzing the data is, make a list of all customers, the total of all active customers is 250 customers, make shipping averages from December 2018 to April 2019 and determine the distance of all customers from the warehouse during in Cileungsi, Bogor. customer data and the number of shipments by area are as shown in Table 2 below.

Table 2. Sample Data Customer Location Avg. Order

\begin{tabular}{|l|r|r|r|r|}
\hline \multicolumn{1}{|c|}{ Area } & Number & Average & \% Customer & \% Qty/Days \\
\hline Jakarta & 98 & 3.696 & $32 \%$ & $14 \%$ \\
\hline Bogor & 37 & 3.791 & $12 \%$ & $14 \%$ \\
\hline Banten & 29 & 6.676 & $10 \%$ & $25 \%$ \\
\hline Bekasi & 25 & 6.332 & $8 \%$ & $24 \%$ \\
\hline Surabaya & 25 & 736 & $8 \%$ & $3 \%$ \\
\hline Bandung & 21 & 768 & $7 \%$ & $3 \%$ \\
\hline Depok & 19 & 868 & $6 \%$ & $3 \%$ \\
\hline Cianjur & 14 & 400 & $5 \%$ & $1 \%$ \\
\hline Cibubur & 7 & 53 & $2 \%$ & $0 \%$ \\
\hline Malang & 6 & 232 & $2 \%$ & $1 \%$ \\
\hline Bali & 4 & 551 & $1 \%$ & $2 \%$ \\
\hline Subang & 3 & 29 & $1 \%$ & $0 \%$ \\
\hline Sidoarjo & 3 & 95 & $1 \%$ & $0 \%$ \\
\hline Cirebon & 2 & 288 & $1 \%$ & $1 \%$ \\
\hline Cikarang & 2 & 257 & $1 \%$ & $1 \%$ \\
\hline Jonggol & 2 & 15 & $1 \%$ & $0 \%$ \\
\hline Tasik & 2 & 1.451 & $1 \%$ & $5 \%$ \\
\hline Medan & 1 & 564 & $0 \%$ & $2 \%$ \\
\hline Cipanas & 1 & 22 & $0 \%$ & $0 \%$ \\
\hline Sukabumi & 1 & 10 & $0 \%$ & $0 \%$ \\
\hline Purwakarta & 1 & 0 & $0 \%$ & $0 \%$ \\
\hline Lombok & 1 & - & $0 \%$ & $0 \%$ \\
\hline Solo & 1 & - & $0 \%$ & $0 \%$ \\
\hline
\end{tabular}

Based on the conditions in the table 2 above the most customers the company is in the area of Jakarta, Bogor, Tangerang, and Bekasi, with a total of $60 \%$, with details of Jakarta of $32 \%$, Bogor 11\%, Tangerang $10 \%$ and Bekasi of $8 \%$. for the customer category based on the amount of shipping Tangerang is an area with the highest number of shipments of $25 \%$, then Bekasi by $24 \%$. for Jakarta and Bogor each at $14 \%$, if summed up by Jakarta, Bogor, Tangerang and Bekasi area operators reached $76 \%$.

Based on the conditions, focus delivery is in Jakarta and surrounding areas. Figure 9 shows the shipping route to customers by the company location. company customers spread from the Banten and Bali regions, then there are terraces located in Medan and Lombok. to manage delivery now the company uses 12 trucks with details truck Capacity 11 Ton are 1 truck, 6 Ton 1 truck, 4.5 Ton 1 truck, 2.5 Ton 6. Truck, 1 Ton 1 Truck and 5-ton 2 truck, with total Capacity 23 Ton.

\section{B. Truck Capacity and Assignment}

As discussed earlier, the limitation, in this case, is the number of trucks owned by the company is fixed, while the number of requests and locations is not fixed every day. The following table 3 is a list of trucks owned by the company. DBSCAN clustering in this paper uses 
MATLAB software. the total data used is 250 data which is the actual shipment from December 2018 to April 2019. to calculate the original data, a smaller scale is created by dividing the data into one thousand. The data used is customer location data that is calculated from the point of delivery of the meat warehouse in the Gandoang, Cileungsi district.

The second data used is the average number of shipments based on the request of each customer. the data entered into MATLAB software. After input data, in the software, we determine the value of epsilon and minpoints as a target.

The epsilon value used is 0.7 with minpoints 3 . value of 0.7 indicates the distance of delivery trucks from a central warehouse in Cileungsi district. The minpoints are the minimum number of data at the epsilon radius. based on these conditions, the density of the number of shipments is average to the distance of the customer from the central warehouse. can be seen in the following Fig 4.

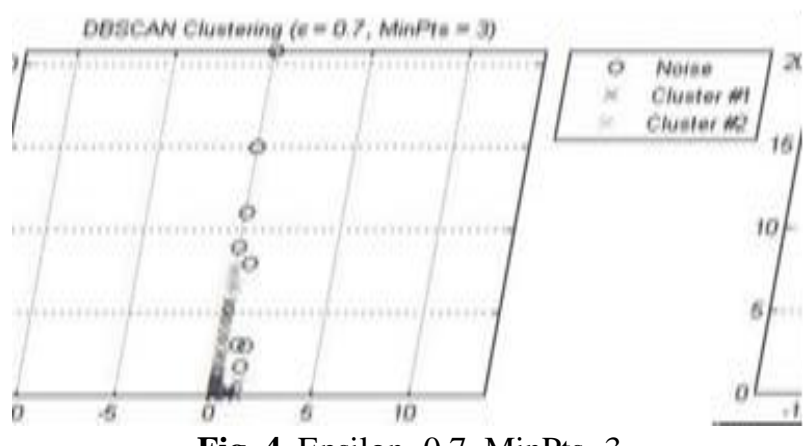

Fig. 4. Epsilon=0.7, MinPts $=3$

Based on Figure 4, 2 clusters are produced based on density and have 8 noise, as Fig 5 .

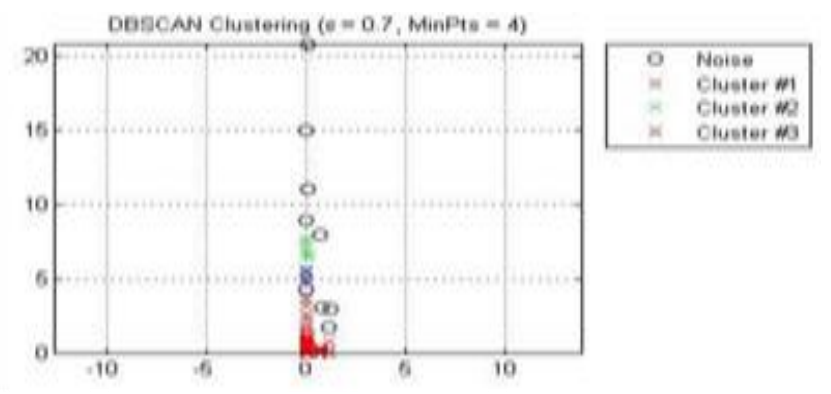

Fig. 5. Epsilon $=0.7$, MinPts $=4$

Based on Figure 5, 3 clusters are produced based on density and there is 9 noise. to maximize density the author tries to convert the minpoints data to 2 from these conditions resulting in 3 clusters and obtained 6 noise. with this condition, the smallest noise is 6 noise with epsilon 0.7 and min points 2 , as presented on Fig 6.

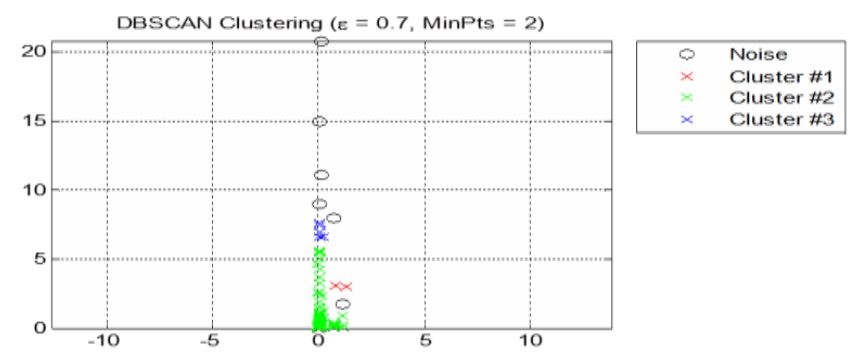

Fig. 6. Epsilon $=0.7$ dan $\mathrm{MinPts}=2$

\section{Truck Assignment}

Based on epsilon values above 0.7 and minpoint 2, the truck is divided as follows, as on Table 3.

Table 3. Result of clustering

\begin{tabular}{|l|l|l|l|}
\hline No & \multicolumn{1}{|c|}{ Cluster } & \multicolumn{1}{|c|}{ Truck Assignments } & \multicolumn{1}{c|}{ Area } \\
\hline 1 & Cluster 1 & 2 truck & Banten (Tangerang, Serang and Cilegon) \\
\hline 2 & Cluster 2 & 7 Truck & Jakarta, Bogor, Tangerang and Bekasi \\
\hline 3 & Cluster 3 & 2 Truck & Malang and Surabaya \\
\hline 4 & Noise & 1 Truck & Bali dan Unscheduled request or noise. \\
\hline
\end{tabular}

Based on the conditions stated in the table above, the distribution of trucks based on clustering results is Cluster 1 total 2 trucks for the Banten area, namely the Tangerang area, Serang and Cilegon, this is consistent with the data that in total shipping this area accounts for $25 \%$ of the total shipment and $10 \%$ of the total number of customers. Cluster 2 totaling 7 trucks for Jakarta, Bekasi, Depok, Bogor, Karawang and Bandung district areas. This is in line with the number of total shipments that the area accounted for $59 \%$.

\section{Conclusions}

Clustering of beef delivery activities by using density-based clustering or DBSCAN on 250 active customers, the data used is the distance and location of customers from the central warehouse and the average amount of delivery to customers. the customer's location covers the island of Java which is spread from Cilegon Banten to Bali province. the results of clustering are using BDSCAN with epsilon 0.7 or the presence of customers at a radius of 7,000 km with the value of minpoints 2 . With these conditions, 3 clusters are based on customer density and 6 noise. The next research is optimizing routing by considering the reverse logistics aspect. wherein the beef logistic industry this happens a lot, so when determining the needs of trucks to fulfill customer delivery requests must also consider the withdrawal capacity of unsold, or damaged products or products that must be withdrawn with various reasons. clustering with more complete parameters such as driver availability and shipping costs. besides Clustering is also done based on the shipping area for optimum routing delivery and assignment truck. 


\section{REFERENCES}

[1] A. Rushton, P. Croucher, and P. Baker, "The Handbook of Logistics \& Distribution Management", Kogan Page Limited Publisher, London, UK. $4^{\text {th }}$ edition, 2010, pp. 3-31.

[2] A. Lindgren, A. Doria, and O. Schelen. (2003). Probabilistic Routing in Intermittently Connected Networks. ACM SIGMOBILE Mobile Computing and Communications Review. Vol. 7, pp. 19-20. Available: https://dl.acm.org/doi/10.1145/961268.961272

[3] A. Singh, "Improving efficiency and reducing waste for sustainable beef supply chain," Ph.D. dissertation, Norwich Bus. Sch., Univ. of East Anglia, London, UK, 2018.

[4] S. M. Gupta, "Reverse Supply Chains: Issues and Analysis". Boca Rotan, USA: CRC Press Taylor \& Francis Group, $1^{\text {st }}$ ed. 2013, pp. 83-97.

[5] I. P. Vlachos. (2014). Reverse food logistics during the product life cycle. Int. J. Integr. Supply Manag., vol. 9(1-2), no. 1, pp. 49-73.

[6] A. S. Devi, I. K. G. D. Putra, and I. M. Sukarsa. (2017). Implementasi Metode Clustering DBSCAN pada Proses Pengambilan Keputusan. Lontar Komput. J. Ilm. Teknol. Inf., vol. 6, no. 3, p. 185.
[7] E. Schubert, J. Sander, M. Ester, H. P. Kriegel, and X. Xu. (2017). DBSCAN Revisited, Revisited: Why and How You Should (Still) Use DBSCAN. ACM Trans. Database Syst., vol. 42, no. 3, pp. 1-21.

[8] R. Shah and S. Jain. (2016). Stock Market Value Prediction Using DBSCAN Algorithm. International Journal of Advanced Research in Computer Engineering \& Technology vol. 5, no. 3, pp. 808-810.

[9] J. Gan and Y. Tao. (2015). DBSCAN Revisited: Misclaim, Un-Fixability, and Approximation. Proceedings of the 2015 ACM SIGMOD International, pp. 519-530.

[10] Y. He, H. Tan, W. Luo, S. Feng, and J. Fan. (2014). MRDBSCAN: A scalable MapReduce-based DBSCAN algorithm for heavily skewed data. Front. Comput. Sci., vol. 8, no. 1, pp. 83-99.

[11] S. Kisilevich, F. Mansmann, and D. Keim. (2010). P-DBSCAN: A density based clustering algorithm for exploration and analysis of attractive areas using collections of geo-tagged photos. COM.Geo '10: Proceedings of the 1st International Conference and Exhibition on Computing for Geospatial Research \& Application. No. 10, pp. 274-277. 